\title{
Respiratory Disorders in Aluminum Smelter Workers
}

\author{
Johny Kongerud, MD, PhD and Vidar Søyseth, MD, PhD
}

\begin{abstract}
Objectives: Summarizing the knowledge status, including the morphology, possible etiological factors, and clinical expression of aluminum potroom asthma and chronic obstructive pulmonary disease related to aluminum potroom exposure. Methods: A review of the literature from the last two decades as it appears in PubMed. Results: There is substantial evidence for the existence of potroom asthma, although the incidence seems to decline over the last 10 years. Increased mortality from chronic obstructive pulmonary disease and longitudinal decline in forced expiratory volume in the first second of expiration has been shown in aluminum potroom workers. Morphological manifestations in bronchial biopsies and the inflammatory markers NO and eosinophils in airway tissue and blood are consistent with asthma in general. The causative agent(s) is (are) not known. Conclusions: Reduction of exposure and cessation of smoking seem to be the major preventive measures to avoid respiratory disorders in the aluminum industry.
\end{abstract}

A luminum is used in a broad range of merchandise and in industries like food packing, construction, and transportation, and associated industries. ${ }^{1}$ The production of aluminum has increased globally as a consequence of increased industrialization in many developing countries and emerging economies, as well as greater demand for aluminum products. Aluminum has now become the world's second-most used metal after steel.

Aluminum production is accompanied by emissions of dust and gases potentially harmful to the workers and the local environment. Despite enhanced safety measures such as partially shielding of the production cells (pots) and automating of previous manual work, there are probably still reasons to focus on preventive measures to avoid respiratory disorders in aluminum smelter workers. The aims of this review were to summarize the present knowledge of the occurrence of potroom asthma (PA) and other respiratory disorders in the aluminum industry, their pathophysiological manifestations, possible etiological factors, and clinical expression.

\section{METHODS}

Our group published, in 1994, a review article on aluminum PA and the Norwegian experience in this field, including an overview of the process of aluminum production involving electrolytic technology as well as types of exposures. ${ }^{2}$ The present article reviews and discusses primarily new knowledge achieved in the period 1993 until 2012 with regard to occupational asthma. In addition, we are reviewing the literature on lung function decline and chronic obstructive pulmonary disease (COPD) among the aluminum production workers. It was beyond the scope of this article to prepare a state-ofthe-art critical review from this broad thematic area. Therefore, we

From the Department of Respiratory Medicine (Dr Kongerud), Rikshospitalet Oslo University Hospital; Faculty of Medicine (Drs Kongerud and Søyseth), University of Oslo; and Department of Respiratory Medicine (Dr Søyseth), Akershus University Hospital, Loerenskog, Norway.

This is an open-access article distributed under the terms of the Creative Commons Attribution-NonCommercial-NoDerivatives 3.0 License, where it is permissible to download and share the work provided it is properly cited. The work cannot be changed in any way or used commercially.

The authors declare no conflicts of interest.

Address correspondence to: Johny Kongerud, MD, PhD, Department of Respiratory Medicine, Rikshospitalet, Oslo University Hospital, PB 4950 Nydalen, 0424 Oslo, Norway (johny.kongerud@medisin.uio.no).

Copyright (C) 2014 by American College of Occupational and Environmental Medicine

DOI: 10.1097/JOM.0000000000000105 performed a literature search limited mainly to PubMed, excluding non-English languages except two articles in Norwegian.

The search strategy intended to be broad to maximize the capture of citations of peer-reviewed publications. The following search strategy was conducted, using MeSH (Medical Subject Headings) terms: Asthma (refined with subheadings: etiology, epidemiology) OR Pulmonary Disease, Chronic Obstructive (refined with subheadings: epidemiology, diagnosis, etiology, mortality, physiopathology, pathology, prevention and control, radiography, rehabilitation) AND Occupational Diseases AND Aluminium. On the basis of their experience, two expert authors selected "valid" articles from a pool of 58 citations. In addition, we supplemented the citation pool through the manual assessment of the reference lists including other published reviews or single publications.

\section{Cross-Sectional Studies}

\section{Symptoms}

Until 1980, most studies of occupational asthma were singlecase reports, descriptions of a number of cases, and prevalence studies. Probably because of the methodological insufficiency of prevalence and case studies, conflicting opinions developed as to the existence and number of PA cases. In an overview by Abramson et $\mathrm{al},{ }^{3}$ the prevalence of PA ranged from $0 \%$ to $14 \%$. In a crosssectional study among a random sample of a general population in a Norwegian county, Bakke et $\mathrm{al}^{4}$ found that the odds ratio (OR) of obstructive lung disease (ie, self-reported asthma or COPD) in subjects who had worked with aluminum production and processing was 2.7 (95\% confidence interval [CI], 1.2 to 6.1$)$ compared with subjects who had never worked in the aluminum industry (Table 1). The main limitation of this study is that the estimates were based on 40 exposed subjects. Thus, the results were very vulnerable to selection bias. Moreover, the details about the exposure were sparse.

Chan-Yeung et $\mathrm{al}^{5}$ investigated the prevalence of respiratory symptoms among 1510 employees in an aluminum smelter in British Columbia. The index group consisted of potroom workers $(n=797)$, of whom 495 workers spend more than $50 \%$ of their working time in the potrooms (high exposure), whereas 302 workers spend less than $50 \%$ of their working time in the potrooms (medium exposure). The remaining subjects worked in the casting departments or offices (references). The researchers found an increased prevalence of cough $(22.6 \%$ vs $14.0 \%)$ and wheeze $(17.1 \%$ vs $10.5 \%)$ in the high-exposure group compared with references (Table 1). They did not, however, find any subjects with PA. The choice of references could be questioned, because the environment in the casting house is partly shared with the potrooms. In a cross-sectional study among potroom workers in seven Norwegian aluminum plants, the prevalence of work-related asthmatic symptoms, that is, the combination of dyspnea and wheezing reducing during days off work, occurred in $15 \%$ of the workers with an exposure period of 10 years or more and in $8 \%$ of the workers who had been employed for less than 5 years. ${ }^{6}$ The OR for work-related asthmatic symptoms increased with increasing duration of exposure in the potrooms after controlling for sex, age, familial disposition for asthma, allergy, smoking, and use of airway protection (Table 1).

A cross-sectional study among 1529 male employees in two Australian aluminum smelters was conducted by Fritschi et al. ${ }^{7}$ In one of the plants, it was found that rhinitis was the only symptom reported more commonly by the potroom employees than by 
TABLE 1. Cross-Sectional Studies: Prevalence of Symptoms, Airflow Limitation, and Pulmonary Function

\begin{tabular}{|c|c|c|c|c|c|c|c|}
\hline \multirow[b]{2}{*}{ Symptoms } & \multirow[b]{2}{*}{$n$} & \multirow[b]{2}{*}{ Exposure } & \multirow[b]{2}{*}{ Outcome } & \multicolumn{2}{|c|}{ Prevalence, $n(\%)$} & \multirow[b]{2}{*}{ Effect (OR) } & \multirow[b]{2}{*}{ Adjustments } \\
\hline & & & & Index & Reference & & \\
\hline \multicolumn{8}{|l|}{ General population } \\
\hline Bakke et $\mathrm{al}^{4}$ & 629 & Al-p: ever vs never & OLD & $9(23)$ & $76(13)$ & $2.7(1.2-6.1)$ & Age, smoking, allergy \\
\hline \multicolumn{8}{|l|}{ Occupational population } \\
\hline \multirow[t]{4}{*}{ Chan-Yeung et $\mathrm{al}^{5}$} & & $\begin{array}{l}\text { Potroom vs unexp } \\
\text { Potroom }\end{array}$ & & & & & \\
\hline & 495 & $\geq 50 \%$ time $(\mathrm{H})$ & Cough & $112(23)$ & & & \\
\hline & 302 & $<50 \%$ time $(\mathrm{M})$ & & $52(17)$ & & & \\
\hline & 713 & $U \exp (\mathrm{U})$ & & & $100(14)$ & $\mathrm{H} v s \mathrm{U}, P<0.05$ & \\
\hline \multirow[t]{2}{*}{ Søyseth and Kongerud ${ }^{8}$} & 370 & Cur TotF, $\mathrm{mg} / \mathrm{m}^{3}$ & & & & & \\
\hline & & $\geq 0.5 \mathrm{vs}<0.5$ & WASTH & $12(6)$ & $19(12)$ & $3.7(1.4-9.6)$ & Age, smoking, allergy \\
\hline \multirow[t]{3}{*}{ Kongerud et al ${ }^{6}$} & 1760 & Duration, yr & & & & & Age, smoking, allergy \\
\hline & & $5-9$ vs $0-4$ & WASTH & $43(9)$ & $50(8)$ & $1.6(1.0-2.5)$ & - \\
\hline & & $\geq 10$ vs $0-4$ & WASTH & $96(15)$ & $50(8)$ & $3.4(2.1-5.8)$ & - \\
\hline Fritschi et $\mathrm{al}^{9}$ & & & & & & & Age and smoking \\
\hline Smelter A & 924 & Potroom vs adm & Wheeze & $30(18)$ & $15(5)$ & $3.8(1.9-7.6)$ & - \\
\hline Smelter B & 605 & - & Wheeze & $15(8)$ & $8(4)$ & $1.7(0.7-4.3)$ & - \\
\hline Smelter A & 924 & - & Ch.tightn & $22(14)$ & $13(4)$ & $3.1(1.5-6.5)$ & - \\
\hline Smelter B & 605 & - & Ch.tightn & $10(5)$ & $9(5)$ & $0.9(0.4-2.5)$ & - \\
\hline
\end{tabular}

Adm, administration; Al-p, aluminum production; Ch.tightn, chest tightness; cur TotF, current exposure to total fluorides; FEV 1 , forced expiratory flow in the first second of expiration; H, high exposure; M, medium exposure; $n$, the number of subjects; OR, odds ratio; OLD, asthma or chronic pulmonary disease; U, unexposed; WASTH, work-related asthma-like symptoms.

administration employees. In the other plant, potroom workers had about five times greater odds of reporting each of the work-related symptoms than the administration group (Table 1). The likelihood for reporting work-related symptoms increased with time of employment among the potroom workers. The authors commented that the difference in results seen between the potrooms in the two different smelters may be a reflection of the age of the smelter, the type of respiratory equipment used, or the selection process for employees at the two different plants. In another article from this study, the authors found that subjects with the highest cumulative exposure to fluoride (more than $0.16 \mathrm{mg} / \mathrm{m}^{3} \times$ years) and inspirable dust (more than $2.9 \mathrm{mg} / \mathrm{m}^{3}$ years) were two to four times more likely to report work-related wheeze and chest tightness than were unexposed subjects. ${ }^{8}$

Another cross-sectional study conducted in a German aluminum smelter ${ }^{10}$ investigated the combined influence on the respiratory health of smoking and exposure in an aluminum potroom. No significant effects of potroom work on the prevalence of respiratory symptoms could be detected. Nevertheless, the prevalence of symptoms, that is, wheezing, dyspnea, and cough, was higher among the nonsmoking potroom workers than among the nonsmoking controls (office, laboratory, workshop, and gate employees) and the study was small $(n=131)$.

van Rooy et $\mathrm{al}^{11}$ published, in 2011, results from a crosssectional study conducted among 182 workers in an aluminum cast house in the Netherlands. Lung function and questionnaire data on respiratory symptoms were compared to a general population sample and an internal reference group. Average daily mean exposure to inhalable dust, metals, hydrogen fluoride (HF), fluoride salts, and sulfur dioxide $\left(\mathrm{SO}_{2}\right)$ was relatively low compared with reference values. Airflow patterns in the hall were disturbed regularly and resulted in pot emissions with high concentration of fluorides. Peak exposures to chlorine $\left(\mathrm{Cl}_{2}\right)$ gas occurred intermittently because of production process disturbances. Workers reported significantly more respiratory symptoms - that is, continuous trouble with breathing (prevalence ratio [PR], 2.5), repeated trouble with breathing (PR, 1.8), wheezing (PR, 1.4), asthma attack (ever) (PR, 2.8), and doctor-diagnosed asthma (PR, 2.6). The cast house is a work environment with quite different exposures than those being seen in the potrooms, although some of the probably important exposures for PA like $\mathrm{HF}, \mathrm{SO}_{2}$, and fluoride salts are present in both settings, thereby supporting the evidence of an exposure health effect.

\section{Pulmonary Function}

In a general population in Norway, Bakke et $\mathrm{al}^{4}$ found that the OR for airflow limitation, that is, forced expiratory volume in the first second of expiration $\left(\mathrm{FEV}_{1}\right)$ /forced vital capacity (FVC) less than 0.7 , was 1.5 (95\% CI, 0.6 to 4.0 ), among subjects who had worked with production and processing in the aluminum industry compared with individuals who have never worked in the aluminum industry. ${ }^{4}$ In an aluminum smelter in British Colombia, Chan-Yeung et $\mathrm{al}^{5}$ found that $\mathrm{FEV}_{1}$ was higher among the references than the high-exposure group (Table 1). Kongerud et $\mathrm{al}^{7}$ found that OR of airflow limitation increased with increasing duration of employment (Table 1). In this study, airflow limitation was defined as the lower decile of standardized $\mathrm{FEV}_{1}$.

\section{Longitudinal Studies}

\section{Symptoms}

To our knowledge, our group conducted the first inception cohort study in the aluminum industry ${ }^{12}$ on the basis of questionnaires. The probability of developing dyspnea and wheezing was $7 \%$ for people who had never smoked and $23 \%$ for current smokers during the first 2 years of employment. Adjusting for possible misclassification of disease, these figures are reduced to $3 \%$ and $10 \%$, respectively.

In 2006, Taiwo et $\mathrm{al}^{13}$ published the incidence of asthma among aluminum workers on the basis of a register study from Alcoa Inc in North America. This company maintains a number 
of computerized data sets on its US workforce, and the sources of data include human resources, insurance claims (non-work-related), medical surveillance, injury, and industrial hygiene records. This study was designed to assess whether asthma occurs excessively among potroom workers, and if so, to delineate dose-response relationship for possible causal risk factors. Of the 12,918 individuals comprising the study population, there were 896 with a diagnosis of asthma at baseline (prevalence 6.9\%). Therefore, the "at-risk cohort" was defined as the remaining 12,002 male hourly employees at the 13 locations for whom there were 46,672 person years of follow-up during the 7-year study period. Potroom employees made up $10 \%$ of the study population, with an average age of 43.7 years. Over the 5 years of follow-up, the annual incidence rates among potroom workers and nonpotroom workers were $1.17 \%$ and $0.95 \%$, respectively, and the asthma incidence ratio between potroom and nonpotroom workers after adjusting for smoking was 1.40 (95\% CI, 1.0 to 1.9$)$.

Although bivariate analyses showed a relationship between asthma incidence and exposure to total fluoride, gaseous fluoride, particulate fluoride, $\mathrm{SO}_{2}$, and smoking, only the effect of gaseous fluoride (relative risk $[R R]=5.1$ per $\mathrm{mg} / \mathrm{m}^{3}$ gaseous fluoride) and smoking $(R R=7.7)$ remained significant in a multivariate model. Potroom asthma seemed to occur at doses within regulatory guidelines, and multivariate analyses showed that the asthma hazard ratio increased by 5.09 (95\% CI, 2.45 to 10.56$)$ per $1 \mathrm{mg} / \mathrm{m}^{3}$ increase of HF exposure (Table 2). Norwegian physicians are obliged to report occupational diseases to the Labor Inspection Authority, and the register of this notification was used to study the cases of occupational asthma. ${ }^{15}$ On an average, 223 annual cases of occupational asthma were reported in the study period (1995 to 1999). The highest incidences of notifications were found in the primary aluminum industry and in bakers, car painters, and welders. During the 5-year study period, a total of 1113 cases fulfilled the criteria for asthma, and 356 cases were from the aluminum industry.

Leira $^{16}$ published in 2008 (in Norwegian) another study from the registry of the Norwegian Labor Inspection Authority, looking at, among other things, the changes of PA in the aluminum industry from 1995 and until 2001. The number of reported cases of PA had declined since 1995 but was, in 2001, still high, counting 27 cases among approximately 5000 workers, which indicate an occurrence of 540 per 100,000 person years. It is known that the number of new cases in this register is substantially underestimated. In Finland, the registration of occupational asthma is known to be reliable and in the general population it is estimated that 40 to 50 of 100,000 persons each year get occupational asthma. In the light of the latter estimate, there are indications of a need to further lower the exposure levels in the aluminum industry to protect workers from PA and other respiratory diseases.

Donoghue et $\mathrm{al}^{14}$ reported, in 2011, the incidence of occupational asthma in the seven aluminum smelters of Australia and New Zealand from 1991 to 2006. All smelters undertook regular medical surveillance of employees throughout the study, including respiratory questionnaires and spirometry. Exposure data were collected for each year of the period 1996 to 2006. Nevertheless, not all smelters collected exposure data every year. In total, there were 329 incident cases of occupational asthma over the period, and 180 cases were classified as PA. The total number of employees for all smelters combined at the start of the study was 6869 , and at the last registration in 2006, there were a total of 5498 employees. The incidence of occupational asthma across all smelters combined was highest in 1992 at $9.46 / 1000$ /year declining to $0.36 / 1000$ /year in 2006, which is a $96.2 \%$ reduction in incidence. There were statistically significant correlations between the incidence rate of occupational asthma and geometric means of each of the following exposure variables: respirable particulate, total fluoride, gaseous HF, and particulate fluoride. The correlation coefficient (Spearman) was greatest for total fluoride $(r=0.5)$. There were also statistically significant declines in all exposure variables measured over the study period.

\section{Pulmonary Function}

Longitudinal studies of pulmonary function among employees in the aluminum smelters are, however, sparse. Chan-Yeung et $\mathrm{al}^{17}$ followed up their cross-sectional study from 1980 to 1986. Among 985 employees who participated in both surveys, 586 (59\%) did not change their exposure status. The overall annual decline in $\mathrm{FEV}_{1}$ $\left(\mathrm{dFEV}_{1}\right)$ was $64.1 \mathrm{~mL} /$ year (mean initial age, 38.3 years). They

TABLE 2. Longitudinal Studies: Symptoms

\begin{tabular}{|c|c|c|c|c|c|c|c|c|}
\hline \multirow[b]{2}{*}{ Symptoms } & \multirow[b]{2}{*}{$N$} & \multicolumn{2}{|c|}{ Exposure } & \multirow[b]{2}{*}{ Outcome } & \multicolumn{2}{|c|}{ Incidence } & \multirow[b]{2}{*}{ Effect } & \multirow[b]{2}{*}{ Adjustments } \\
\hline & & Entity & Scale & & $n$ & $\operatorname{IR}\left(10^{-3} \mathrm{yr}\right)$ & & \\
\hline \multirow[t]{3}{*}{ Kongerudand Samuelsen ${ }^{12}$} & 1301 & TotF & $\mathrm{mg} / \mathrm{m}^{3}$ & WASTH & & & HR & Sex, age, smoking \\
\hline & & - & $0.4-0.7$ vs $<0.4$ & - & NA & NA & $3.35(1.51-7.41)$ & \\
\hline & & - & $>0.7$ vs $<0.4$ & - & NA & NA & $5.20(2.02-13.3)$ & \\
\hline Taiwoet al ${ }^{13}$ & 12,022 & Gas HF & $\mathrm{mg} / \mathrm{m}^{3}$ & D asthma & NA & NA & $5.09(2.45-10.6)$ & Smoking \\
\hline \multirow[t]{12}{*}{ Donoghue et $\mathrm{al}^{14}$} & NA & TotF & Year: $\mathrm{mg} / \mathrm{m}^{3}$ & PA & & & $\rho=0.50(P<0.001)$ & None \\
\hline & 5,944 & - & 1996: 0.61 & - & 16 & 2.69 & & \\
\hline & 5,853 & - & 1997: 0.73 & - & 19 & 3.25 & & \\
\hline & 5,789 & - & 1998: 0.50 & - & 11 & 1.90 & & \\
\hline & 5,725 & - & 1999: 0.76 & - & 21 & 3.67 & & \\
\hline & 5,583 & - & 2000: 0.83 & - & 16 & 2.87 & & \\
\hline & 5,583 & - & 2001: 0.60 & - & 7 & 1.25 & & \\
\hline & 5,622 & - & 2002: 0.39 & - & 10 & 1.78 & & \\
\hline & 5,476 & - & 2003: 0.46 & - & 13 & 2.37 & & \\
\hline & 5,475 & - & 2004: 0.37 & - & 4 & 0.73 & & \\
\hline & 5,568 & - & 2005: 0.25 & - & 3 & 0.54 & & \\
\hline & 5,498 & - & 2006: 0.37 & - & 2 & 0.36 & & \\
\hline
\end{tabular}

$\rho$ : Spearman rho; HF, hydrogen fluoride (gas); HR, hazard ratio; $N$, total number of subjects; $n$, number of incident cases; NA, not applicable; TotF, total fluorides; WASTH, work-related asthmatic symptoms, that is, the combination of dyspnea and wheezing improving on rest days. 
found no association between $\mathrm{dFEV}_{1}$ and exposure, but the difference in $\mathrm{dFEV}_{1}$ between current smokers and never smokers was $11.6 \mathrm{~mL} /$ year $(P=0.02)$. Because the longitudinal analyses were restricted to subjects who did not change their exposure status, the lack of exposure effect could be due to selection bias.

A follow-up of spirometry surveys among potroom workers was done at a Norwegian aluminum plant from 1986 to $1992 .{ }^{18}$ The workers were investigated annually, and annual estimates of exposure to particulates and fluorides were available. Smoking habits were also updated annually. An autoregressive regression model was applied to estimate the change in $\mathrm{FEV}_{1}$ between two consecutive examinations. The mean and standard deviation of the time between two consecutive examinations were 12.0 and 0.6 months, respectively (Table 2). After adjustment for relevant confounders, the mean change in $\mathrm{FEV}_{1}$ per $\mathrm{mg} / \mathrm{m}^{3}$ exposure to particulates between two consecutive spirometries was $-11.9 \mathrm{~mL}(P=0.004)$ and $-43.1 \mathrm{~mL}$ $(P=0.004)$ between smokers and nonsmokers. We have, however, not been able to find any study where the association between exposure measurements and the incidence of airflow limitation or COPD in employees in the aluminum industry has been explored.

\section{Mortality Studies}

Cause-specific mortality among aluminum employees has been investigated in two Norwegian and three Canadian studies (Table 3). The oldest cohort was investigated by Rønneberg. ${ }^{19}$ This study encompassed 1209 subjects who had been hired in a Norwegian smelter in 1922 or later. They should have died between 1962 and 1991 or still be alive in 1991. Death certificates were obtained from the Central Bureau of Statistics, where all deaths in Norway were registered during this period. Chronic obstructive pulmonary disease deaths were defined as deaths caused by chronic bronchitis, asthma, or emphysema. Analyses were restricted to subjects who had been employed for at least 3 years. An increased overall standardized mortality from COPD was found (Table 3 ), but they failed to find any dose-response relationship between mortality and the cumulative exposure of coal tar pitch and pot emissions (qualitative scale). This was, however, a small study encompassing 24,996 person years and nine deaths from COPD. Data on smoking habits were not available.

In another Norwegian study, Romundstad et $\mathrm{al}^{20}$ investigated mortality from nonmalignant diseases among subjects who had been employed for 3 years or more in six Norwegian aluminum smelters (Table 3). Exposure data on total fluorides were available, and data on smoking habits were available in three of the plants. The underlying cause of death both without and with contributing cause of death was used as outcomes. The data in Table 3 are based on COPD (ie, chronic bronchitis, asthma, or emphysema) as the underlying cause of death. The total observation time was 239,246 years, and the total number of deaths from COPD was 112 (Table 3). A doseresponse relationship was found between deaths from COPD and cumulative exposure to total fluorides. The results did not change notably if COPD as the contributing cause of death was included or if the analyses were restricted to the plants where smoking data were available.

Gibbs et $\mathrm{al}^{21,22}$ investigated mortality at three smelters (Søderberg) in Quebec. The employees were divided into two cohorts whether they were hired before or after January 1, 1951 (Table 3). Data on mortality were obtained from the Canadian $\mathrm{Na}-$ tional Mortality Database, where data on all death records in Canada are stored. Mortality from COPD was defined as that from chronic bronchitis, asthma, or emphysema. It was not specified whether mortality was restricted to underlying cause of death or contributing cause of death was included. Data on smoking status were available for most employees. Exposure was expressed as cumulative exposure to benzene-soluble matter and benzo[a]pyrene. Among employees hired before 1951, a dose-response relationship between COPD and BSM was found even after adjustment for smoking habits $(P$ $<0.001$ ). Among subjects employed after 1950 , no dose-response relationship between COPD mortality and cumulative exposure to benzo[a]pyrene was found. Nevertheless, standardized mortality ratio was significantly elevated (Table 3 ).

Friesen et $\mathrm{al}^{23}$ investigated mortality among employees in an aluminum smelter in British Colombia (Table 3). Employees in a power generating station were also included. Information about mortality was obtained from the Canadian National Mortality Database during 1957 to 1999 . Chronic obstructive pulmonary disease deaths were defined as deaths caused by chronic bronchitis, asthma, or emphysema. It was not taken into account whether the diagnosis was taken as the underlying diagnosis of death or contributing cause of death. Smoking habits were available in $88 \%$ of the employees. Exposure was expressed as cumulative exposure to benz[a]pyrene. Standardized mortality rate was significantly lower in the exposed group than the general population, and in the internal analyses, no doseresponse relationship between COPD mortality and benz[a]pyrene was found (Table 3). Nevertheless, the number of cases was small, and the mortality in the first tertile was lower than that in tertiles 2 and 3 .

\section{Symptoms and Cases}

In our previous review article, ${ }^{2}$ we describe the typical symptoms of aluminum PA. Desjardins et $\mathrm{al}^{24}$ described, in a case report, aluminum PA confirmed by monitoring of $\mathrm{FEV}_{1}$. A 35-year-old man, lifelong nonsmoker with no history of asthma or atopy, was hired by an aluminum plant that had begun its operation in 1986. Preemployment screening was normal. He worked with changing of anodes in a prebake plant and experienced episodes of cough and dyspnea, which resolved during withdrawal from work in January and December 1991. He resumed work in the potrooms in March 1992 , but his dyspnea recurred at work and at night with a $25 \%$ drop in peak expiratory flow rates (PEFs) associated with nonspecific bronchial hyperresponsiveness (NSBHR) ( $\mathrm{PC}_{20}$ histamine 1.0 $\mathrm{mg} / \mathrm{mL}$ ). Assessment of the bronchial response to the occupational exposure in potrooms revealed a pattern of dual asthmatic response, accompanied by a drop in $\mathrm{PC}_{20}$ metacholine from 5.1 to $0.7 \mathrm{mg} / \mathrm{mL}$.

Kongerud et $\mathrm{al}^{25}$ published an investigation of 14 potroom workers suspected of having asthma. They were examined by serial measurements of peak flow at home and work, symptom diaries, and measurements of methacholine reactivity before and after a 3-week holiday. There was a good correlation between daily symptom scores and peak flow measurements; these showed changes characteristic of occupational asthma in 10 workers, with increased diurnal variation in peak flow and consistent deterioration in relation to work exposure. One further record showed probable occupational asthma, and two showed consistent small changes in peak flow related to work exposure more in keeping with an irritant effect. Only one record was inadequate. Methacholine reactivity on a workday was within the reference range in 9 of 13 subjects. A doubling of $\mathrm{PC}_{20}$ methacholine occurred in five of nine subjects with occupational asthma in whom repeated estimations were possible.

In 2000, the first case of aluminum asthma in a foundry worker was reported. ${ }^{26} \mathrm{He}$ had a positive specific challenge test to aluminum chloride, and the authors raised the possibility that PA is due to a reaction to aluminum fluoride. A 46-year-old smoker developed cough and chest tightness starting 3 hours after coming to work, and improving on days away from work. He had worked as a caster of molten aluminum for 19 years in the rolling mill. He was nonatopic on skin testing, baseline spirometry showed airflow obstruction, and he had moderate histamine reactivity. Two-hourly PEF measurements showed a significant occupational effect, and specific bronchial provocation testing showed a dual asthmatic reaction after 3 -minute exposure to aluminum chloride $(10 \mathrm{mg} / \mathrm{mL})$ with a negative reaction to potassium chloride. After replacement, his bronchial 


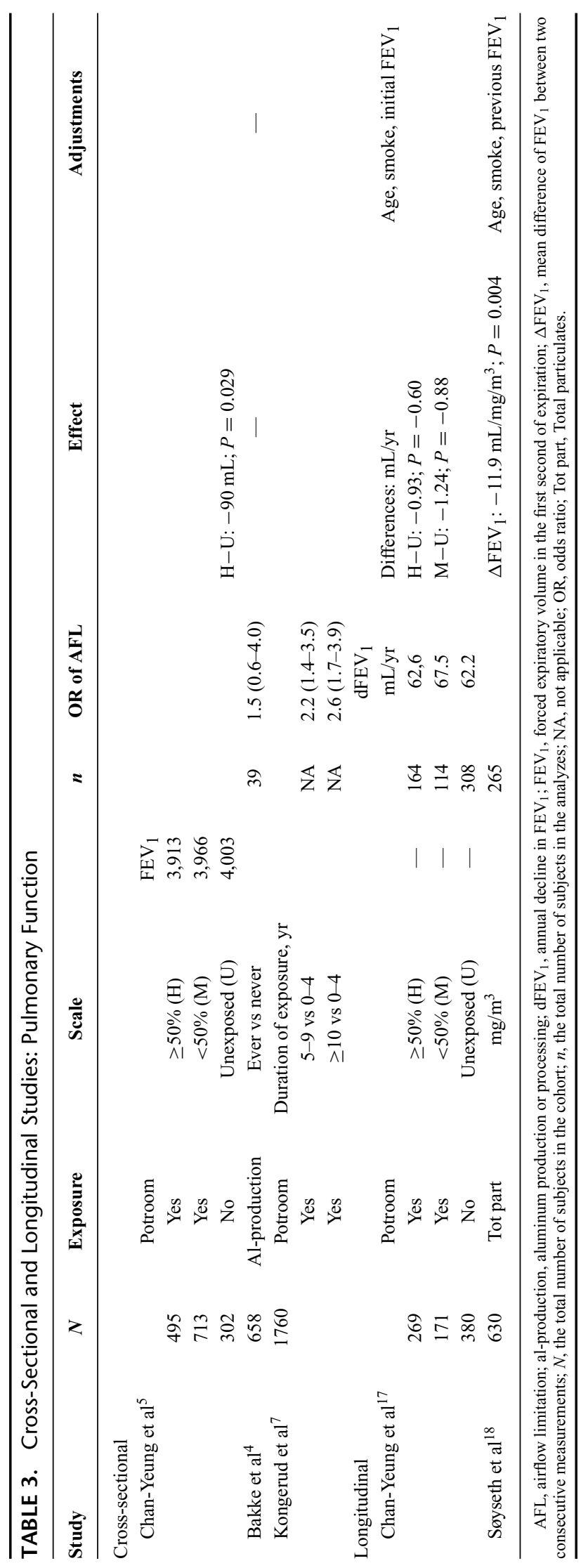


reactivity returned to normal, but he still had asthmatic symptoms in relation to nonspecific stimuli.

\section{Exposure and Respiratory Disorders: Mechanisms}

In relation to development of PA, fluorides in general have been associated with the condition. Frostad ${ }^{27}$ published an article suggesting that the increased occurrence of asthma he observed in primary aluminum production was related to dust and "fluoride" gas. His observation of the increased risk of asthma has later been confirmed by several reports from Australia, Canada, Europe, and the United States. Fifty years later, the Nordic aluminum industry started a longitudinal study of PA.

In a separate cross-sectional study, which included a detailed exposure classification, a significant association between current fluoride exposure and work-related asthmatic symptoms was found. ${ }^{6}$ The adjusted OR for work-related asthmatic symptoms was 3.7 (95\% CI, 1.4 to 9.6) for subjects exposed to total fluorides more than 0.5 $\mathrm{mg} / \mathrm{m}^{3}$, as compared with subjects exposed to less this level. The longitudinal study of 1301 new workers revealed a similar association between total fluoride exposure and asthmatic symptoms. ${ }^{12} \mathrm{~A}$ dose-effect relationship between current fluoride exposure and asthmatic symptoms was also observed. Subjects exposed to a current fluoride level of 0.41 to 0.80 and more than $0.80 \mathrm{mg} / \mathrm{m}^{3}$ had an RR of 3.4 (95\% CI, 1.5 to 7.4$)$ and 5.2 (95\% CI, 2.0 to 13.3 ), respectively, as compared with subjects exposed to fluoride levels of less than $0.41 \mathrm{mg} / \mathrm{m}^{3}$. In this longitudinal study, a multiplicative interaction was found between smoking and fluoride exposure. On the basis of the data from this study, the RR of developing asthmatic symptoms is estimated to be 10.5 for smokers exposed to an average fluoride level more than $0.5 \mathrm{mg} / \mathrm{m}^{3}$, as compared with people who had never smoked and were exposed to levels less than $0.5 \mathrm{mg} / \mathrm{m}^{3}$.

Over the last 15 to 20 years, irritant-induced asthma has been acknowledged as a type of occupational asthma. ${ }^{28}$ As no specific immunological mechanism has been shown in aluminum PA, asthma caused by irritants may well be a plausible mechanisms. Two reports, one from Australia ${ }^{29}$ and one from Norway, ${ }^{30}$ suggested that bronchial responsiveness decreases when exposure to irritant ceased in the aluminum industry. On the basis of this knowledge, Søyseth et $\mathrm{al}^{31}$ designed a longitudinal study to investigate the relation between bronchial responsiveness and plasma fluoride levels in 26 aluminum potroom workers who reported work-related asthmatic symptoms, and also the association between plasma fluoride levels and workplace exposure to fluoride and particulates was investigated. Repeated measurements of bronchial responsiveness to methacholine and regular analyses of plasma fluoride levels were performed. A positive association was found between bronchial responsiveness and plasma fluoride levels, such that an increase in the plasma fluoride level of $10 \mathrm{ng} / \mathrm{mL}$ was associated with an increase in the dose-response slope by a factor of 1.11 (95\% CI, 1.05 to 1.17). Plasma fluoride levels were associated with the total work atmospheric fluoride concentration but not with total particulates. The authors concluded that bronchial responsiveness in aluminum potroom workers reporting work-related asthmatic symptoms seemed to be related to plasma levels of fluoride.

Sulfur dioxide has been less focused on than fluorides as a causal agent for PA. In two Australian aluminum smelters, an inception cohort study was conducted where 446 employees (77\% of eligible workforce) participated over a period of 9 years. ${ }^{32}$ Cumulative exposures between interviews were estimated from job histories by using a site-specific task exposure matrix based on routine air monitoring for the following airborne contaminants: fluorides, $\mathrm{SO}_{2}$, coal tar pitch volatiles (as benzene-soluble fraction), oil mist, and inhalable dust. Participants completed a Medical Research Council respiratory questionnaire, spirometry, and methacholine challenge test. Data were analyzed with generalized estimating equations to allow for repeated measurements of each participant. Wheeze and chest tightness, the two symptoms most closely related to asthma, showed associations with occupational exposures. Sulfur dioxide exposure was significantly associated with these symptoms, bronchial hyperresponsiveness to methacholine (a feature of asthma), airflow limitation (reduced $\mathrm{FEV}_{1} / \mathrm{FVC}$ ratio), and longitudinal decline in lung function. Fluoride exposure was associated with the same outcomes but less strongly. Inhalable dust and the benzene-soluble fraction were associated with symptoms of asthma and NSBHR. Although many of the exposures were highly correlated, further modeling suggested that of the known respiratory irritants, $\mathrm{SO}_{2}$ was more likely than fluoride to be primarily responsible for the symptoms observed. Fluoride, inhalable dust, and $\mathrm{SO}_{2}$ were the most important airborne contaminants associated with effects on lung function. Likewise, using repeated measurements of bronchial responsiveness, Søyseth et $\mathrm{al}^{31}$ found a positive association between the dose-response slope of methacholine and plasma fluorides in aluminum potroom workers reporting work-related asthma-like symptoms. The sensitivity of $\mathrm{PC}_{20}$ metacholine less than $32 \mathrm{mg} / \mathrm{mL}$ to detect work-related asthma-like symptoms was, however, low $(35 \%){ }^{33}$

Two human experimental studies have been conducted to assess the ability of HF to induce respiratory tract inflammation. In the first study, increases in upper airway symptoms were observed in individuals exposed to $\mathrm{HF}$ in the range of 0.2 to $5.2 \mathrm{mg} / \mathrm{m}^{3}$ for 1 hour. ${ }^{34}$ Significant increases in the percentage of CD3-positive cells (T-lymphocytes) in the bronchial portion of the lower respiratory tract, as assessed via bronchoalveolar lavage performed 3 weeks before exposure and 24 hours after exposure, was also observed at exposure more than $2.5 \mathrm{mg} / \mathrm{m}^{3}$ but not at $0.6 \mathrm{mg} / \mathrm{m}^{3}$. Nevertheless, no significant alterations in lung function or lower airway symptoms were observed. ${ }^{34}$ The second study with a similar study design assessed upper airway inflammation via nasal lavage. ${ }^{35}$ An inflammatory response in the nasal mucosa was observed after a 1-hour exposure to 3.3 to $3.9 \mathrm{mg} / \mathrm{m}^{3} \mathrm{HF}$. Seven of the 10 tested subjects also reported upper airway symptoms (specific symptoms were not presented); most of the subjects scored the severity of the symptoms as very mild to mild.

Mechanisms for possible development of asthma after HF exposure in the aluminum industry have not been clarified, because the vast majority of the HF molecules will be absorbed in the upper airways. Inerle-Hof et $\mathrm{al}^{36}$ have suggested that the hygroscopic behavior of inhaled "dry" water soluble particles may be important for the deep lung penetration of $\mathrm{HF}$ and $\mathrm{SO}_{2}$. Repeated peak and even low exposures may induce chronic inflammatory changes in the airway mucosa as seen in the experimental studies of HF and lead to "irritant induced" asthma. Accidental high HF exposure may have a direct toxic effect, causing reactive airways dysfunction syndrome. ${ }^{37}$

As a result of the longitudinal study in Norwegian aluminum smelter workers and also in the conformity with experimental studies of HF exposure, the Norwegian labor directorate lowered threshold limit value for total fluorides from 2.5 to $0.5 \mathrm{mg} / \mathrm{m}^{3}$. Other threshold limit values were not changed, although it was emphasized that fluoride could be a marker for other pollutants that might play a role in occupational asthma occurring among the production workers.

Occupational asthma caused by aluminum welding has been described by several authors. There are, however, despite similarities, quite large differences between the exposure in potrooms and exposure caused by aluminum. ${ }^{38-40}$ We have, therefore, in this review article, not included or discussed occupational asthma seen in other types of industries where aluminum welding may occur. Welders are exposed to many different agents, depending on which kind of metal they are welding on and what kind of electrodes under various welding processes being used. Therefore, it is not possible to draw reliable associations between such exposure and the exposure in aluminum potrooms. 


\section{Morphology and Inflammation Markers}

To our knowledge, there has been no characterization of the inflammatory nature of PA on the basis of bronchial biopsies until Sjåheim et $\mathrm{al}^{41}$ published the results from such a study in 2004. Bronchial biopsy specimens from 20 asthmatic workers, 15 healthy workers, and 10 nonexposed controls were analyzed. Median reticular basement membrane thickness was significantly increased in both asthmatic workers and healthy workers compared with nonexposed controls. Nonsmoking asthmatic workers had significantly increased median density of lamina propria CD 45 leucocytes and eosinophils, and significantly increased concentrations of exhaled NO compared with nonsmoking healthy workers and nonexposed controls. Fewer leucocytes were observed in asthmatic smokers than in nonsmokers. Both eosinophilic and noneosinophilic phenotypes of asthma were recognized in the potroom workers, and signs of airway inflammation were also observed in healthy workers.

Eosinophils are principally tissue-dwelling cells, but it is well recognized that asthma and asthma-like symptoms may be reflected by increased levels of blood eosinophils. ${ }^{42}$ The blood eosinophil count has been shown to increase during asthmatic attacks in potroom workers, ${ }^{43}$ and case reports of PA with blood eosinophilia have been described. ${ }^{44}$ Kongerud et $\mathrm{al}^{25}$ showed a decrease in serum eosinophils among subjects in potroom workers when not exposed for 3 weeks, although atopy is not more common in workers with work-related, asthma-like symptoms than in the general smelter workforce. ${ }^{9}$

Sorgdrager et $\mathrm{al}^{45}$ conducted a nested case-control study with preemployment data of 364 potroom workers (182 cases and 182 controls). Cases were workers unable to work because of workrelated respiratory disease, meeting the criteria for PA. Preemployment eosinophil count was significantly related to the occurrence of PA, although the mean number of eosinophils in cases was within the reference range (less than 275 per $\mathrm{mm}^{3}$ ). Thirty-nine of the 44 individuals with blood eosinophil counts in the upper range of normal developed PA with time.

In a Norwegian cross-sectional study of 338 workers, Sjåheim et $\mathrm{al}^{46}$ showed that the OR for PA was 4.2 for workers with eosinophils $400 \times 10^{6}$ cells $/ \mathrm{L}$ or more, compared with workers with eosinophils less than $200 \times 10^{6}$ cells $/ \mathrm{L}$. An attenuation of the blood eosinophil increase was actually observed in smoking asthmatic workers, suggesting an immune-modulating effect of smoking.

Two decades ago, there was not any preferred immunological test for asthma in the aluminum industry. ${ }^{2}$ There is still no valid test for PA; however, Lund et al. ${ }^{47}$ found that exposure to potroom pollutions was associated with increased concentration of exhaled NO in nonsmoking subjects. A study group comprising 180 male subjects and 40 comparable control subjects recruited from the same aluminum plant was examined by measurements of exhaled and nasal concentration of NO, spirometry, and a questionnaire on respiratory symptoms as a part of an annual health surveillance program. In nonsmokers, the concentrations of exhaled NO were higher in the potroom workers than in the controls. The two groups did not differ in spirometry and asthma-like symptoms. Nonsmoking potroom workers with asthma-like symptoms had higher concentration of exhaled NO than those with no symptoms. The authors suggested that nitric oxide in exhaled air could be an early marker of airway inflammation in aluminum potroom workers.

\section{Genetic Factors and Asthma}

To our knowledge, there has been only one article published in the area of genetics and PA. ${ }^{48}$ The subjects for this study were members of an inception cohort of 161 newly hired potroom workers (Spokane, Washington). Fifty-two subjects agreed to participate, and all had at least one follow-up evaluation after their baseline assessment. Five individuals had new asthma-like symptoms and increased NSBHR, five had only new asthma-like symptoms, and three had only increased NSBHR. Genotyping was performed for the $\beta_{2}$-adreno receptor, high-affinity immunoglobulin $\mathrm{E}$ receptor, and tumor necrosis factor. No associations were found between PA case status and genotype. Nevertheless, the number of subjects was small, and the authors suggested that a larger numbers of subjects needed to be tested.

\section{Predisposing Host Factors}

Barnard et $\mathrm{al}^{49}$ assessed individual employee risk factors for occupational asthma in primary aluminum smelting in a nested casecontrol study. Workers were included in the study if they had their first employment medical examination between 1982 and 1995. The cohort was followed until December 31, 2000. In the cohort of 545 workers, there were 45 cases diagnosed with PA, and 4 controls per case were matched for the same year of preemployment and age within \pm 5 years. There was a significant positive association between hay fever diagnosed either at or during employment and PA with an adjusted OR of 3.58 (95\% CI, 1.57 to 8.21 ). A higher $\mathrm{FEV}_{1} / \mathrm{FVC} \%$ (FER) at employment reduced the risk of developing PA. The risk of PA was more than three times higher in individuals with an FER of $70 \%$ to $75 \%$ than in individuals with FER of $80 \%$ or more.

Sorgdrager et al ${ }^{50}$ studied whether preventive measures such as reduction of exposure and the introduction of the histamine provocation test as a selection instrument resulted in a lower incidence of PA or a longer latency time between the commencement of employment and the occurrence of PA. A total of 179 cases of PA diagnosed between 1970 and 1990 were studied. After introduction of the preemployment histamine provocation test, the incidence density of PA decreased substantially but cases still continued to occur (incidence density 11.6 per 1000 person years in 1976 to 1981 vs 2.5 in 1982 to 1990). Even though fluoride exposure was at levels lower than those thought to confer risk for the development of respiratory disorders, a reduction in the mean exposure levels may have contributed to the decrease. The latency time did not differ when subjects with bronchial hyperresponsiveness were screened out, suggesting that agents in the potroom atmosphere act principally as "inducers" and not as simple airway irritants.

Sorgdrager et $\mathrm{a}^{51}$ also evaluated the effectiveness of preemployment screening in the prevention of aluminum PA. He computed the predictive value of a positive test result, the number of medical assessments needed to reduce the number of new cases by one, and the number of rejections for the job needed to reduce the number of new cases by one. The results depended on the incidence rates, but the overall conclusion was that personal risk indicators like low $\mathrm{FEV}_{1}$ level in preemployment examination, atopic history, and high blood eosinophils at preemployment were far from effective and should not be used as a selection instrument.

\section{Prognosis}

In our previous review article, there was substantial evidence from follow-up studies that subjects with PA, even after several years of nonexposure, had persistent symptoms, NSBHR, or both. ${ }^{2}$ This is not very different from other causes of occupational asthma. Wergeland et $\mathrm{al}^{52}$ examined 35 men with PA after an average follow-up period of 2.5 years after cessation of exposure, and the group had an increased RR of morning cough $(\mathrm{RR}=1.7 ; 95 \% \mathrm{CI} 0.6$ to 5.1 ), dyspnea on exertion $(\mathrm{RR}=2.8 ; 95 \% \mathrm{CI} 0.9$ to 8.4$)$, and wheezing $(\mathrm{RR}=$ $6.1 ; 95 \%$ CI 2.3 to 16.3 ) compared with controls from the same plant, in a 1:2 matched analysis. Ten subjects reported persisting asthma, dyspnea at night, or dyspnea on exertion. In a New Zealand smelter, 47 subjects with PA, diagnosed and transferred to other jobs between 1971 and 1986, were reexamined in $1986 .{ }^{29}$ Twelve had frequent or persistent symptoms of asthma, and a further 11 were taking some regular medication for intermittent milder symptoms. Persistence of bronchial responsiveness has also been reported several years after cessation of exposure. In one study, 67\% retained their NSBHR after 
cessation of exposure. ${ }^{53}$ In a Norwegian study of 12 workers with $\mathrm{PA}$, an improvement of NSBHR with a twofold increase in $\mathrm{PC}_{20}$ was shown in seven of eight subjects who were hyperreactive at the time of relocation. ${ }^{30}$

During the last decade, additional knowledge of the benefit of relocation has been produced, which supports earlier findings suggesting that PA may develop into a chronic disease. Among 179 cases of PA identified by Sorgdrager et al, 122 workers were still present at the factory 5 years after their relocation to an exposure-free department. A follow-up study was carried out among the 122 workers. A long exposure time (the time interval between start of exposure and diagnosis) seemed as a significant factor affecting $\mathrm{FEV}_{1} \%$ predicted at follow-up. The authors concluded that the results of this study gave support for additional prevention measures to be taken, such as early recognition of work-related respiratory complaints and repeated education.

In his doctoral thesis, Sorgdrager ${ }^{54}$ looked at determinants of medical outcome in 39 workers with PA 5 years after transfer to exposure-free departments. Increased bronchial responsiveness was still present in $47 \%$ of the workers. All PA cases with an atopic history had increased bronchial responsiveness at follow-up. Cases that were detected by means of consulting hours had statistically significant higher mean $\mathrm{FEV}_{1} \%$ of predicted as compared with cases detected by periodic medical examination. Sickness absence in workers with PA was slightly higher as compared with the whole plant population. The authors conclude that once diagnosed, patients with PA need to be carefully followed up and educated to prevent further development of health impairments. Generally it seems wise to introduce regularly surveillance of potroom workers with spirometry and respiratory questionnaires, so workers with PA can be detected at an early stage and removed from exposure as soon as possible to improve their prognosis. Similarly, Wergeland et $\mathrm{al}^{52}$ found that a considerable proportion of workers with PA had respiratory symptoms 1 to 43 months after relocation to nonexposed jobs compared with never-exposed workers. Nevertheless, improvement of bronchial responsiveness is to be expected after relocation to less-exposed or nonexposed jobs. ${ }^{29,30}$

\section{Prevention}

As already described, Donoghue et $\mathrm{al}^{14}$ could show a $96 \%$ reduction of the incidence of PA from 1991 to 2006 accompanied by a significant decline over the years for total fluoride, particulate and gaseous fluoride, $P$ values $0.010,0.031$, and 0.007 , respectively. Respirable particles did not decrease significantly. From 2004 to 2006 , total fluorides was measured less than $0.40 \mathrm{mg} / \mathrm{m}^{3}$ and gaseous fluoride 0.13 to 0.17 (geometric means).

Reduction of exposure by the use of airway protection is common in all type of work with inhalable pollution. There is, however, scarce documentation of such equipment reducing symptoms or improving prognosis. Kongerud and Rambjør ${ }^{56}$ studied the efficiency of the Racal Airstream helmet respirator in improving PEFs and reducing symptoms (dyspnea, wheezing, and cough) in 19 aluminum potroom workers with respiratory complaints. Peak expiratory flow readings and symptom recording from a 2 -week working period with use of the respirator were compared with a period when the 3M 9906 disposable mask was used. The study was designed as a randomized, parallel, cross-over study with five or six daily measurements of PEF and daily symptom recording. A significant number of workers ${ }^{56}$ had a higher mean peak flow in the helmet period than in the nonhelmet period $(P<0.01)$, while symptoms did not improve significantly in the helmet period. Objective evidence of respiratory protection was observed for the group of workers as a whole, but the effect on symptoms as well as individual effect on peak flow was minor in most workers. There are, however, circumstances and types of jobs with peaks of exposure that such types of personal equipment are recommended. Prevention by selection has been discussed in another section of this article and has not been shown to successfully prevent development of PA. Also, such selection rather than reduction of exposure may also be looked upon as unethical.

\section{The Evidence of PA and Work-Related COPD}

\section{PA: Occupational Asthma or Work-Aggravated Asthma?}

Occupational asthma is a disease characterized by airflow limitation, NSBHR, or both associated with inflammation due to causes and conditions attributable to a particular occupational environment and not to stimuli encountered outside the workplace. ${ }^{28}$ It can be divided into three subgroups: (1) immunoglobulin Emediated occupational asthma, (2) occupational asthma due to specific occupational agents with unknown pathological mechanisms, and (3) irritant occupational asthma. In addition, work-aggravated asthma, that is, worsening of preexisting asthma due to causes and conditions attributable to particular exposures encountered at work.

Potroom asthma was first described in three Norwegian reports. ${ }^{27,43,55}$ The cause(s) and mechanism(s) of this condition are, however, still unknown. First, immunoglobulin E-mediated asthma is unlikely, because these cases are usually caused by sensitizing to high-weight molecular agents that usually have a biological origin. Low-weight molecular agents acting as sensitizers by unknown mechanism are also less likely though it cannot be excluded. Gylseth et $\mathrm{al}^{57}$ found, in one study, an inhalable fiber (aluminum sodium tetrafluoride-diameter $0.1 \mu \mathrm{m}$ and length $5 \mu \mathrm{m}$ ) that could be a candidate

It is probably most likely that PA is mediated by irritants. Such agents may induce asthma by accidental high exposures or repeated exposures at moderate to low levels of exposure. Irritant asthma caused by accidental high exposure (ie, "reactive airways dysfunction syndrome" $)^{37}$ is very unlikely, as such episodes have not been described in the aluminum industry. Thus, PA is probably mediated by repeated low to moderate levels of exposure to irritants. Such agents may, however, also act as provokers of asthma in subjects with preexisting or latent asthma. Hence, differentiating between occupational irritant asthma and work-aggravated asthma is difficult.

The following arguments favor that PA represents an occupational irritant asthma:

- Serial peak flow measurements have identified an occupational pattern in 10 of 14 workers who reported the combination of chest tightness and wheezing, improving on rest days. ${ }^{45}$

- Repeated measurements of bronchial responsiveness have shown that the level of bronchial responsiveness is associated with the level of exposure to irritants as well as blood fluorides. ${ }^{31,32}$

- In many aluminum plants, subjects with a history of asthma are precluded from employment in the potrooms.

- The prevalence of NSBHR among potroom workers seems to be low. asthma.

Thus, it is most likely that PA is irritant-induced occupational

\section{COPD in the Aluminum Industry}

The most widely used definition of COPD was introduced by the Global Initiative on Obstructive Pulmonary Disease in $2001 .{ }^{58}$ This definition has later been revised several times, the latest in 2011. In all these definitions, "enhanced chronic inflammatory response in the airways and the lung to noxious particles or gases" has been retained (www.goldcopd.org/). Although tobacco smoking is the dominating cause of the disease, this definition opens the possibility of other causative agents of COPD such as pollutants encountered at work. 
The association between COPD and occupational exposure can be investigated using several approaches. Ideally, the relationship between the incidence of COPD, for example, expressed as airflow limitation, and occupational exposure should be investigated using prospective studies in occupational cohorts. Until now, results from no such studies in the aluminum industry have been published. Alternatively, an indirect approach can be applied by investigating the association between annual decline in lung function and occupational exposure can be used. Actually, Chan-Yeung et $\mathrm{al}^{17}$ found no difference in $\mathrm{FEV}_{1}$ decline between unexposed employees and potroom workers in a follow-up of 820 employees at a plant in British Colombia. Nevertheless, only $54 \%$ of those who were included at the initial survey were available at the follow-up. Thus, selective dropout rate could have distorted the estimates toward a zero effect, which has been described in similar settings. ${ }^{59}$ The difference between two consecutive measurements of $\mathrm{FEV}_{1}$ was, however, negatively associated with exposure to particulates during 6-year follow-up of 630 potroom workers. ${ }^{18}$ In this study, an autoregression model was used that did not allow for estimation of annual decline in lung function.

Because of the risk of selection bias, cross-sectional studies using the prevalence of COPD or airflow limitation are less valid than follow-up studies. Nonetheless, Kongerud et $\mathrm{al}^{7}$ found that the OR of airflow limitation increased with increasing duration of exposure (Table 3 ). In a prospective follow-up study, it was found that $\mathrm{FEV}_{1}$ decreased with $11.4 \mathrm{~mL}$ per $\mathrm{mg} / \mathrm{m}^{3}$ increase in particulate exposure. ${ }^{18}$ The main limitation of this study was the limited number of participants and that fact that the autoregressive model does not give the outcome as a lung volume decline per exposure unit per year.

The association between COPD mortality and aluminum production has been investigated in five studies (Table 4). ${ }^{19-23}$ Occupational mortality studies of COPD have several limitations, such as uncertainty regarding the diagnosis, the possibility of information bias, and their retrospective design. Except one study, where a significant decreased mortality was found, a positive association between aluminum production and mortality was shown.

It has been suggested that COPD caused by occupational exposures may develop as a consequence of persisting obstruction in subjects with occupational asthma. ${ }^{60}$ This hypothesis may also be relevant in the aluminum industry, because employees reporting the combination of dyspnea and wheezing improving on rest days have significantly steeper annual decline in $\mathrm{FEV}_{1}$ than asymptomatic subjects. ${ }^{61}$

\section{SUMMARY}

Most of both cross-sectional and longitudinal studies have shown an increased occurrence of respiratory symptoms in general as well as work-related asthmatic symptoms in aluminum potroom workers compared with controls. Fortunately, the number of workers with PA seems to have decreased during the last decade, concurrent with a decrease in dust and gas exposure in the plants. Mortality studies have shown an increased mortality from COPD, and in cross-sectional studies, an increased number of subjects with airflow limitation have been observed in potroom exposed groups

TABLE 4. Mortality Studies: Chronic Obstructive Pulmonary Disease

\begin{tabular}{|c|c|c|c|c|c|c|c|}
\hline \multirow[b]{2}{*}{ Study } & \multirow[b]{2}{*}{ Obs Years } & \multicolumn{2}{|c|}{ Exposure } & \multicolumn{3}{|c|}{ Outcome } & \multirow[b]{2}{*}{ SMR for the Total Cohort } \\
\hline & & Entity & Scale & Deaths & Entity & Scale & \\
\hline Rønneberg ${ }^{19}$ & 24,996 & Potroom & Yes vs no & Total $=20^{*}$ & SMR & - & $197(P<0.05)$ \\
\hline Romundstad et $\mathrm{al}^{20}$ & 239,246 & Cum F-exp & $\begin{array}{c}\mathrm{mg} / \mathrm{m}^{3} \times \mathrm{yr} \\
0 \\
0.1-7.4 \text { vs } 0 \\
7.5-19.9 \text { vs } 0 \\
\geq 20\end{array}$ & $\begin{array}{c}\text { Total }=112 \\
20 \\
24 \\
32 \\
36\end{array}$ & MRR & $\begin{array}{c}P \text { trend }<0.001 \\
1 \\
1.3(0.7-2.4) \\
1.9(1.1-3.4) \\
2.5(1.5-4.3)\end{array}$ & $121(101-146)$ \\
\hline Gibbs et $\mathrm{a}^{21}$ & 214,023 & BSM & $\begin{array}{c}\mathrm{mg} / \mathrm{m}^{3} \times \mathrm{yr} \\
0 \\
0.1-1.0 \\
2.0-3.9 \\
4.0-7.9 \\
8.0-15.9 \\
16.0-31.9 \\
\geq 32.0\end{array}$ & $\begin{array}{c}\text { Total }=321 \\
21 \\
86 \\
36 \\
41 \\
51 \\
69 \\
17\end{array}$ & SMR & $\begin{array}{c}P \text { trend }<0.001 \\
82(51-125) \\
126(101-156) \\
128(90-177) \\
174(125-236) \\
197(141-259) \\
217(169-274) \\
175(102-280)\end{array}$ & $151(135-168)$ \\
\hline Desjardins et $\mathrm{al}^{24}$ & 172,799 & Cum B(a)P & $\begin{array}{c}\mu \mathrm{g} / \mathrm{m}^{3} \times \mathrm{yr} \\
0 \\
0.1-20.0 \\
20.1-40.0 \\
40.1-80.0 \\
80.1-160.0 \\
160.1-320.0 \\
>320.0\end{array}$ & $\begin{array}{c}\text { Total }=44 \\
4 \\
18 \\
6 \\
4 \\
10 \\
3 \\
0\end{array}$ & SMR & $\begin{array}{c}P \text { trend }>0.2 \\
150(41-384) \\
134(80-213) \\
176(57-411) \\
131(36-336) \\
217(104-399) \\
118(24(344) \\
0(0-382)\end{array}$ & $146(106-196)$ \\
\hline Friesen et $\mathrm{al}^{23}$ & 150,750 & Cum B(a)P & $\begin{array}{c}\mu \mathrm{g} / \mathrm{m}^{3} \times \mathrm{yr} \\
\mathrm{T} 2 \text { vs T1 } \\
\text { T3 vs T1 }\end{array}$ & $\begin{array}{c}\text { Total }=28 \\
8 \\
8\end{array}$ & HR & $\begin{array}{c}P \text { trend }=0.78 \\
1.58(0.63-3.93) \\
1.21(0.47-3.13)\end{array}$ & $64(42-94)$ \\
\hline
\end{tabular}

*Underlying cause of death.

BSM, benzene-soluble matter; Cum B[a]P, cumulative Benso[a]pyrene; Cum F-exp, cumulative exposure to fluorides; HR, hazard ratio; MRR, mortality rate ratio; Obs years, observation years; SMR, standardized mortality rate (per 100,000 years); T1, 0 to $9.77 \mu \mathrm{g} / \mathrm{m}^{3} \times$ year; $\mathrm{T} 2,9.78$ to $36.8 \mu \mathrm{g} / \mathrm{m}^{3} \times$ year; $\mathrm{T} 3$, more than $36.8 \mu \mathrm{g} / \mathrm{m}^{3} \times$ year. 
associated with duration of employment. Nevertheless, increased occurrence of COPD has not been examined in longitudinal studies yet. It is possible that employees with PA have an increased risk of COPD.

Lung function is also undoubtedly affected by potroom exposure, causing an increased longitudinal decline in $\mathrm{FEV}_{1}$ as well as cross-shift changes. Typical cases of occupational asthma have been described, and typical peak flow patterns have been documented. Potroom asthma represents probably an irritant-induced occupational asthma. Morphological manifestations in bronchial biopsies and the inflammatory markers NO and eosinophils in airway tissue and blood are consistent with asthma in general. The causative agent(s) is (are) not known and may be a mixture of two or more irritants that are present in the workplace atmosphere. Unknown sensitizers are less likely although not precluded. Reductions in respiratory symptoms as well as improvements in bronchial responsiveness are to be expected after relocation, but a considerable proportion of relocated subjects still have some symptoms. Genetic factors and preemployment selection have so far not been shown to influence the occurrence of PA. The most important preventive measures are to decrease exposure through decreased pollution in the work atmosphere, use of airway protection during the most-exposed work tasks, and cessation of smoking.

\section{REFERENCES}

1. Kuo SC, Hsieh L-Y, Tsai C-H, Tsai YI. Characterization of PM2.5 fugitive metal in the workplaces and the surrounding environment of a secondary aluminum smelter. Atmos Environ. 2007;41:6884-6900.

2. Kongerud J, Boe J, Søyseth V, Naalsund A, Magnus P. Aluminium potroom asthma: the Norwegian experience. Eur Respir J. 1994;7:165-172.

3. Abramson MJ, Wlodarczyk JH, Saunders NA, Hensley MJ. Does aluminum smelting cause lung disease? Am Rev Respir Dis. 1989;139:10421057.

4. Bakke PS, Baste V, Hanoa R, Gulsvik A. Prevalence of obstructive lung disease in a general population: relation to occupational title and exposure to some airborne agents. Thorax. 1991;46:863-870.

5. Chan-Yeung M, Wong R, MacLean L, et al. Epidemiologic health study of workers in an aluminum smelter in British Columbia. Effects on the respiratory system. Am Rev Respir Dis. 1983;127:465-469.

6. Kongerud J, Gronnesby JK, Magnus P. Respiratory symptoms and lung function of aluminum potroom workers. Scand $J$ Work Environ Health 1990;16:270-277.

7. Fritschi L, Beach J, Sim M, et al. Respiratory symptoms and lung function in two prebake aluminum smelters. Am J Ind Med. 1999;35:491-498.

8. Søyseth V, Kongerud J. Prevalence of respiratory disorders among aluminium potroom workers in relation to exposure to fluoride. $\mathrm{Br} J$ Ind $\mathrm{Med}$. 1992;49:125-130.

9. Fritschi L, Sim MR, Forbes A, et al. Respiratory symptoms and lung-function changes with exposure to five substances in aluminium smelters. Int Arch Occup Environ Health. 2003;76:103-110

10. Radon K, Nowak D, Szadkowski D. Lack of combined effects of exposure and smoking on respiratory health in aluminium potroom workers. Occup Environ Med. 1999;56:468-472.

11. van Rooy FG, Houba R, Stigter H, et al. A cross-sectional study of exposures, lung function and respiratory symptoms among aluminium cast-house workers. Occup Environ Med. 2011;68:876-882.

12. Kongerud J, Samuelsen SO. A longitudinal study of respiratory symptoms in aluminum potroom workers. Am Rev Respir Dis. 1991;144:10-16.

13. Taiwo OA, Sircar KD, Slade MD, et al. Incidence of asthma among aluminum workers. J Occup Environ Med. 2006;48:275-282.

14. Donoghue AM, Frisch N, Ison M, et al. Occupational asthma in the aluminum smelters of Australia and New Zealand: 1991-2006. Am J Ind Med. 2011;54:224-231.

15. Leira HL, Bratt U, Slastad S. Notified cases of occupational asthma in Norway: exposure and consequences for health and income. Am J Ind Med. 2005;48:359-364.

16. Leira HL. Occupational asthma in Norway. Tidsskr Nor Laegeforen. 2008;128:2719-2721.

17. Chan-Yeung M, Enarson DA, MacLean L, Irving D. Longitudinal study of workers in an aluminum smelter. Arch Environ Health. 1989;44:134-139.
18. Søyseth V, Boe J, Kongerud J. Relation between decline in $\mathrm{FEV}_{1}$ and exposure to dust and tobacco smoke in aluminium potroom workers. Occup Environ Med. 1997;54:27-31.

19. Rønneberg A. Mortality and cancer morbidity in workers from an aluminium smelter with prebaked carbon anodes - part III: mortality from circulatory and respiratory diseases. Occup Environ Med. 1995;52:255-261.

20. Romundstad P, Andersen A, Haldorsen T. Nonmalignant mortality among workers in six Norwegian aluminum plants. Scand J Work Environ Health. 2000;26:470-475

21. Gibbs GW, Armstrong B, Sevigny M. Mortality and cancer experience of Quebec aluminum reduction plant workers. Part 2: mortality of three cohorts hired on or before January 1, 1951. J Occup Environ Med. 2007;49:11051123 .

22. Gibbs GW, Sevigny M. Mortality and cancer experience of Quebec aluminum reduction plant workers. Part 3: monitoring the mortality of workers first employed after January 1, 1950. J Occup Environ Med. 2007;49:1269-1287.

23. Friesen MC, Demers PA, Spinelli JJ, Eisen EA, Lorenzi MF, Le ND. Chronic and acute effects of coal tar pitch exposure and cardiopulmonary mortality among aluminum smelter workers. Am J Epidemiol. 2010;172:790-799.

24. Desjardins A, Bergeron JP, Ghezzo H, Cartier A, Malo JL. Aluminium potroom asthma confirmed by monitoring of forced expiratory volume in one second. Am J Respir Crit Care Med. 1994;150:1714-1717.

25. Kongerud J, Søyseth V, Burge S. Serial measurements of peak expiratory flow and responsiveness to methacholine in the diagnosis of aluminium potroom asthma. Thorax. 1992;47:292-297.

26. Burge PS, Scott JA, McCoach J. Occupational asthma caused by aluminum. Allergy. 2000;55:779-780.

27. Frostad EW. Fluorine intoxication in Norwegian aluminium plant workers. Tidsskr Nor Laegeforen. 1936;56:179.

28. Baur X, Sigsgaard T, Aasen TB, et al. Guidelines for the management of work-related asthma. Eur Respir J. 2012;39:529-545.

29. O'Donnell TV, Welford B, Coleman ED. Potroom asthma: New Zealand experience and follow-up. Am J Ind Med. 1989;15:43-49.

30. Søyseth V, Kongerud J, Boe J, Fonneland T. Bronchial responsiveness and work-related asthma in aluminium potroom workers: effect of removal from exposure. Eur Respir J. 1992;5:829-833.

31. Søyseth V, Kongerud J, Ekstrand J, Boe J. Relation between exposure to fluoride and bronchial responsiveness in aluminium potroom workers with work-related asthma-like symptoms. Thorax. 1994;49:984-989.

32. Abramson MJ, Benke GP, Cui J, et al. Is potroom asthma due more to sulphur dioxide than fluoride? An inception cohort study in the Australian aluminium industry. Occup Environ Med. 2010;67:679-685.

33. Kongerud J, Søyseth V. Methacholine responsiveness, respiratory symptoms and pulmonary function in aluminum potroom workers. Eur Respir J. 1991;4:159-166.

34. Lund K, Ekstrand J, Boe J, Sostrand P, Kongerud J. Exposure to hydrogen fluoride: an experimental study in humans of concentrations of fluoride in plasma, symptoms, and lung function. Occup Environ Med. 1997;54:32-37.

35. Lund K, Refsnes M, Ramis I, et al. Human exposure to hydrogen fluoride induces acute neutrophilic, eicosanoid, and antioxidant changes in nasal lavage fluid. Inhal Toxicol. 2002;14:119-132.

36. Inerle-Hof M, Weinbruch $\mathrm{S}$, Ebert M, Thomassen $\mathrm{Y}$. The hygroscopic behaviour of individual aerosol particles in nickel refineries as investigated by environmental scanning electron microscopy. J Environ Monit. 2007;9:301306.

37. Brooks SM, Weiss MA, Bernstein IL. Reactive airways dysfunction syndrome (RADS). Persistent asthma syndrome after high level irritant exposures. Chest. $1985 ; 88: 376-384$

38. Flodin U, Ziegler J, Jonsson P, Axelson O. Bronchial asthma and air pollution at workplaces. Scand J Work Environ Health. 1996;22:451-456.

39. Nemery B. Metal toxicity and the respiratory tract. Eur Respir J. 1990;3:202219.

40. Vandenplas O, Delwiche JP, Vanbilsen ML, Joly J, Roosels D. Occupational asthma caused by aluminium welding. Eur Respir J. 1998;11:1182-1184.

41. Sjåheim T, Halstensen TS, Lund MB, et al. Airway inflammation in aluminium potroom asthma. Occup Environ Med. 2004;61:779-785.

42. Lewis SA, Pavord ID, Stringer JR, Knox AJ, Weiss ST, Britton JR. The relation between peripheral blood leukocyte counts and respiratory symptoms, atopy, lung function, and airway responsiveness in adults. Chest. 2001;119:105-114.

43. Midtun O. Bronchial asthma in the aluminium industry. Acta Allergol. 2012;15:208-221

44. Simonson BG, Sjøberg BG, Rolf C, Haeger-Aronsen B. Acute and long-term airway hyperreactivity in aluminium-salt exposed workers with nocturnal asthma. Eur Respir Dis. 1985;66:105-118. 
45. Sorgdrager B, Pal TM, de Looff AJ, Dubois AE, de Monchy JG. Occupational asthma in aluminium potroom workers related to pre-employment eosinophil count. Eur Respir J. 1995;8:1520-1524.

46. Sjåheim T, Kongerud J, Søyseth V. Blood eosinophils in workers with aluminum potroom asthma are increased to higher levels in non-smokers than in smokers. Am J Ind Med. 2007;50:443-448.

47. Lund MB, Oksne PI, Hamre R, Kongerud J. Increased nitric oxide in exhaled air: an early marker of asthma in non-smoking aluminium potroom workers? Occup Environ Med. 2000;57:274-278.

48. Arnaiz NO, Kaufman JD, Daroowalla FM, Quigley S, Farin F, Checkoway H. Genetic factors and asthma in aluminum smelter workers. Arch Environ Health. 2003;58:197-200.

49. Barnard CG, McBride DI, Firth HM, Herbison GP. Assessing individua employee risk factors for occupational asthma in primary aluminium smelting. Occup Environ Med. 2004;61:604-608.

50. Sorgdrager B, de Looff AJ, Pal TM, van Dijk FJ, de Monchy JG. Factors affecting $\mathrm{FEV}_{1}$ in workers with potroom asthma after their removal from exposure. Int Arch Occup Environ Health. 2001;74:55-58.

51. Sorgdrager B, Hulshof CT, van Dijk FJ. Evaluation of the effectiveness of preemployment screening. Int Arch Occup Environ Health. 2004;77:271-276.

52. Wergeland E, Lund E, Waage JE. Respiratory dysfunction after potroom asthma. Am J Ind Med. 1987;11:627-636.

53. Saric M, Marelja J. Bronchial hyperreactivity in potroom workers and prognosis after stopping exposure. Br J Ind Med. 1991;48:653-655.
54. Sorgdrager B. Doctoral thesis: Potroom asthma. Prevention and prognosis of occupational asthma in aluminium potroom workers. Rijksuniversiteit Groningen. 2002.

55. Evang K. Investigation among Norwegian workmen as to the occurrence of bronchial asthma, acute cryolite poisoning and "fluorosis." Nord Hyg Tidskr. 1938;19:117-148.

56. Kongerud J, Rambjør O. The influence of the helmet respirator on peak flow rate in aluminum potroom. Am Ind Hyg Assoc J. 1991;52:243-248.

57. Gylseth B, Bjorseth O, Dugstad O, Gjonnes J. Occurrence of fibrous sodium aluminumtetrafluoride particles in potrooms of the primary aluminum industry. Scand J Work Environ Health. 1984;10:189-195.

58. Pauwels RA, Buist AS, Calverley PM, Jenkins CR, Hurd SS. Global strategy for the diagnosis, management, and prevention of chronic obstructive pulmonary disease. NHLBI/WHO Global Initiative for Chronic Obstructive Lung Disease (GOLD) Workshop summary. Am J Respir Crit Care Med. 2001;163:1256-1276.

59. Søyseth V, Johnsen HL, Kongerud J. Prediction of dropout from respiratory symptoms and airflow limitation in a longitudinal respiratory study. Scand $J$ Work Environ Health. 2008;34:224-229.

60. Hendrick DJ. Occupational and chronic obstructive pulmonary disease (COPD). Thorax. 1996;51:947-955.

61. Søyseth V, Kongerud J, Kjuus H, Boe J. Bronchial responsiveness and decline in $\mathrm{FEV}_{1}$ in aluminium potroom workers. Eur Respir J. 1994;7: 888-894. 